\title{
Gaps of Service Quality in Private Banks Customers Regarding SERVQUAL in Isfahan, Iran
}

\author{
Mohammad Hosein Moshref Javadi, Ph.D. \\ Faculty of Administrative Science \& Economics, Department of Management, University of \\ Isfahan, Isfahan, Iran \\ E-mail: mhmj20032003@yahoo.com \\ Rohullah Balochianzadeh \\ Faculty of Administrative Science \& Economics, Department of Management, University of \\ Isfahan, Iran \\ E-mail: balochianzadeh@yahoo.com \\ Mohammad Ali Nasirzadeh \\ Faculty of Administrative Science \& Economics, Department of Management, University of \\ Isfahan, Isfahan, Iran \\ E-mail: Nasirzade64@gmail.com
}

Accepted: July 02, 2012 Published: July 31, 2012

Doi:10.5296/jsr.v3i2.2177 URL: http://dx.doi.org/10.5296/jsr.v3i2.2177

\begin{abstract}
Financial liberalization has led to intense competitive pressures and private banks dealing in retail banking are consequently directing their strategies towards increasing service quality level which fosters customer satisfaction and loyalty through improved service quality. This article examines the influence of perceived service quality on customer satisfaction. The aim of this study is to examine the service quality from the perspective of bank customers. Service quality is defined as the degree of equality between customers' expectations and their perceptions of the service received. In this paper, we have used SERVQUAL as a technique to measure service quality in the Private Banks in Esfahan. The aim of this survey is to understand the most important strength and weaknesses of private banks. The results of this study showed that there are service quality gaps between customers' expectations and their perceptions in six dimensions. Furthermore, the private banks have to take improvement actions in mentioned dimensions.
\end{abstract}

Keywords: Banking service, Service quality, Private Banks, Customers satisfaction. 


\section{Introduction}

Private Banks dealing in retail banking Industry is consequently put into lot of pressures due towards increase in global competition. Various strategies are formulated to retain the customer and the key of it is to increase the service quality level. Typically, customers perceive very little difference in the banking products offered by private banks dealing in services as any new offering is quickly matched by competitors. Parasuraman et al (1985) and Zeithaml et al. (1990) noted that the key strategy for the success and survival of any business institution is the deliverance of quality services to customers. The issue of quality management regarding to banking services has drawn considerable attention over the past few years. The move to managed service has increased demands for outcome-based accountability, cost containment, and attention to customer-oriented quality in order to remain competitive in a rapidly changing environment. This dual focus on driving down costs while increasing quality has intensified pressures to understand, measure, and manage quality from a customer perspective. The aim of this paper is to evaluate quality service in banking industry provided by a private bank in Esfahan.

Service quality in retailing is different from any other product/service environment (Bergman and Klefsjo, 1994). Because of the unique nature of retail service, improvements and measurements of quality in retailing cannot be approached in the same way as that of the services perspective. In retail service, it is necessary to look at quality from the perspective of services as well as goods and derive a set of items that accurately measure this construct (Evans and Lindasy, 1996). During the past few decades service quality has become a major area of attention to practitioners, managers and researchers owing to its strong impact on business performance, lower costs, customer satisfaction, customer loyalty and profitability. Service quality is a critical component of customers' perception because it is an antecedent to customer satisfaction. Research suggests that customers do not perceive quality as a one-dimensional concept. Parasuraman et al. (1998) have found that customers consider five dimensions in their assessments of service quality (viz. reliability, responsiveness, assurance, empathy, and tangibles).

Reliability is the ability to perform the promised service dependably and accurately while responsiveness is the willingness to help customers and to provide prompt service. Assurance refers to employees' knowledge and courtesy, and their ability to inspire trust and confidence.

Empathy is the caring, individualized attention given to customers and tangibles are appearance of physical facilities, equipment, personnel and written materials. Based on exploratory and quantitative research, these five dimensions were found to be relevant for the banking, insurance, appliance repair and maintenance, securities, brokerage, long-distance telephone service and automobile repair industries. In banking industry, banking systems provide the same types of services, but they do not provide the same quality of services. Furthermore, customers today are more aware of alternatives and their expectations of service have increased. Service quality can be used as a strategic tool to create a distinctive 
advantage comparing other competitors.

Banks are trying for zero defection and retaining every customer that the company can profitably serve in order to achieve service excellence (Jannadi and Al-Saqqaf, 2000). As customers do not easily articulate banking service qualities, the receiver of the service can only really assess it, thereby making its measurement more subjective than exact. Furthermore, the measurement of banking service quality has to be based on perceived quality rather than objective quality because services are intangible, heterogeneous and their consumption and production occur simultaneously. Lewis and Walsh (1991) believed that service quality is a measure of how well the service level matches customers' expectations. Levis and Booms (1983) perceived service quality as a result of what customers receive it.

Gronroos (1984) defined service quality as perceived by customers and items from a comparison on their expectations of the services they will receive with their perceptions of the performance of the service provider. Expectations are the wants of customers, i.e., what they feel a service provider should offer, while perceptions refer to the customers' evaluation of the service provider. They formulated a service quality model that highlights the main requirements for delivering the expected service quality.

The purpose of this paper is to evaluate the quality of private banks services provided to the customers and to measure the customers' satisfaction. In the following section, the model will be presented.

\section{Review of Literature}

Many scholars and service marketers have explored consumers' cognitive and affective responses to the perception of service attributes in order to benefit by providing what consumers need in an effective and efficient manner. Consumer satisfaction (e.g. Cadott et al, 1997; Churchill \& Surprenant, 1982; Fornell,1992; Oliver, 1997) and PSQ (e.g. Parasuraman et al, 1985, 1988; Zeithaml et al, 1996) have been considered the primary intervening constructs in the area of service marketing because ultimately they lead to the development of consumer loyalty or re-patronization of a product or service. Consumer perception of service quality is a complex process. Therefore, multiple dimensions of service quality have been suggested (Brady \& Cronin, 2001). One of the most popular models, SERVQUAL, used in service marketing, was developed by Parasuraman et al $(1985,1988)$. SERVQUAL is based on the perception gap between the received service quality and the expected service quality, and has been widely adopted for explaining consumer perception of service quality. Originally 10 dimensions of service quality were proposed (reliability, responsiveness, competence, access, courtesy, communication, credibility, security, understanding the consumer, and tangibles). Later these were reduced to five (reliability, responsiveness, empathy, assurances and tangibles). There is general agreement that the aforementioned constructs are important aspects of service quality, but many scholars have been skeptical about whether these dimensions are applicable when evaluating service quality in other 
service industries (Finn \& Lamb, 1991; Cronin \& Taylor, 1992). For example, Cronin \& Taylor (1992) argued that the evaluation of service quality based on the expectation-performance gap derived from Parasuraman et al $(1985,1988)$ is insufficient because much of the empirical research supported performance-based measures of service quality. This has more explanatory power than measures that are based on the gap between expectation and performance (e.g. Babakus \& Boller, 1992; Churchill \& Surprenant 1982). In addition, Kang \& James (2004) argued that SERVQUAL focuses more on the service delivery process than on other attributes of service, such as service-encounter outcomes (i.e. technical dimensions). In other words, the SERVQUAL measurement does not adequately explain a technical attribute of service.

\section{The Proposed Model}

Quality service is a measure of how well the service level delivered matches customer expectations (Gronroos, 1984). The central focus of the study of service quality is the customer gap, the difference between customers' expectations and perceptions of the service(s) received. Expectations are the reference point customers have before experiencing the service whereas perceptions reflect their experience of the service that they have actually received. Hence, firms will strive to close or narrow this gap, i.e. between what is expected and what is received to satisfy their customers and to build long-term relationships with them. SERVQUAL model is one possible method for collecting information on both the perceptions and expectations of customers, which was developed to assess the differences between customers' expectations and perceptions (Parasuraman et al, 1985). The SERVQUAL forms the central part of the gap model for measuring customer-focused quality (Parasuraman et al., 1988). SERVQUAL has been one of the most important contributions to the quality field in the services industry since the last decade. The SERVQUAL instrument identifies five dimensions of service quality that customers routinely use as a way of evaluating services:

Tangibles: the appearance of facilities, equipment, materials, and personnel,

Reliability: the performance of the service in a dependable and accurate manner,

Responsiveness: the willingness of staff to help customers and provide prompt service,

Assurance: the staff's ability to provide courteous and knowledgeable service,

Empathy: the staff's ability to understand the needs of the customer,

The instrument poses a set of structured, paired questions designed to assess these dimensions for both customers' expectations and customers' perceptions. A five-point Likert scale was used for the scoring system with " 1 " representing least important/strongly disagree and " 5 " representing most important/strongly agree. The SERVQUAL instrument is based on the premise that customers who rate expectations higher than perceived services will experience 
service quality that is less than adequate. Conversely, customers who perceive performance as higher than their expectations will rate the service as higher quality. Meanwhile, customers who rate expectations and perceptions with similar scores are satisfied. Perceived quality involves the subjective response of people and is therefore highly relativistic. It is a form of attitude related but not equivalent to satisfaction, and results from a comparison of expectations with perceptions of performance (Parasuraman et al., 1991). This instrument has been utilized to assess the quality of services provided by Private Banks. It includes an examination of customers' expectations and perceptions of private banks service quality. This examination of service quality will enable management to better direct financial resources to improve banking operations in those areas that have the most impact on customers' perceptions of service quality. This examination is essential in today's competitive market.

Despite the criticism of SERVQUAL, no notable measurement techniques or approaches have been put forward as serious alternatives. On the other hand, SERVQUAL remains the most widely applied measure of service quality by academics and practitioners.

Although SERVQUAL has been widely used to measure service quality, no two providers of service are exactly similar. Therefore, we have used SERVQUAL to serve only as a framework. The proposed model does not follow all of the original 22 SERVQUAL items; instead, items were modified, added and deleted when planning the survey instrument. In addition, we have added one extra dimension to the previous dimensions to fit the situation of the banking industry.

\section{Methodology and Data}

\subsection{Questionnaire}

The questionnaire used in this study was adopted from the work of Parasuraman et al (1988). It comprised of two parts. The first part is used to measure customers' expectations and the second is used to measure customers' perceptions. The items used in both questionnaires are adapted from those in the revised version of SERVQUAL. Each form includes six dimensions to be measured. These are: tangibles, reliability, responsiveness, assurance, empathy, and accessibility; the ability to access Private Banks easily and conveniently. Each dimension included some statements and every respondent is asked to say his expectations and perceptions of service quality provided by Private Banks. Thus, the differences between these expectations and perceptions represent the extent to which service quality provided is above or below the required level. Before distributing the questionnaires, a pilot survey was conducted in order to find any problem of the questionnaire and if any necessary 


\section{Macrothink}

modifications have to be made.

\subsection{Data Collection}

Data collection method is highly influenced by the methodology chosen. The population of this study is directly means all customers who receive banking services from private banks. It is practically rather impossible to examine the whole population of interest due to limitation of resources such as time, money, and people. The sample size $(n=390)$ was computed and the respondents ( $n=65$ respondent for every private bank) were randomly selected from the customers of 52 branches of private banks located in Esfahan consisting of Mellat, Parsian, Saman, Pasargad, Eghtesad Novin and Kar Afarin. A profile of sampled respondents is presented in Table 1.

Table1: Demographics of Respondents

\begin{tabular}{|c|c|c|c|}
\hline Demographic & Frequency & Valid (\%) & Cumulative (\%) \\
\hline \multicolumn{4}{|l|}{ Panel A: Age Group } \\
\hline 18-30 years old & 41 & 10.6 & 10.6 \\
\hline 31-40 years old & 70 & 17.7 & 28.3 \\
\hline 41-50 years old & 93 & 23.8 & 52.1 \\
\hline 51-60 years old & 90 & 23.1 & 75.2 \\
\hline 61-70 years old & 49 & 12.7 & 87.9 \\
\hline $\begin{array}{l}71 \text { years old and } \\
\text { above }\end{array}$ & 47 & 12.1 & 100 \\
\hline Total & 390 & 100 & \\
\hline \multicolumn{4}{|l|}{ Panel B: Gender } \\
\hline Male & 205 & 52.7 & 52.7 \\
\hline Female & 185 & 47.3 & 100 \\
\hline Total & 390 & 100 & \\
\hline \multicolumn{4}{|l|}{ Panel C:Education Level } \\
\hline $\begin{array}{l}\text { Postgraduate } \\
\text { Degrees }\end{array}$ & 40 & 10.4 & 10.4 \\
\hline Bachelor Degree & 87 & 22.3 & 32.7 \\
\hline Technician & 54 & 13.9 & 46.6 \\
\hline Diploma & 133 & 34 & 80.6 \\
\hline $\begin{array}{l}\text { High School } \\
\text { Qualification }\end{array}$ & 55 & 14 & 94.6 \\
\hline uneducated & 21 & 5.4 & 100 \\
\hline Total & 390 & 100 & \\
\hline
\end{tabular}

4.3 Research Hypotheses 


\section{I Macrothink}

The following hypotheses were developed and tested:

$\mathbf{H}_{\mathbf{1}}$ : There is a significant difference between customer expectations and their perceptions of reliability.

$\mathbf{H}_{2}$ : There is a significant difference between customer expectations and perceptions of responsiveness.

$\mathbf{H}_{3}$ : There is a significant difference between customer expectations and their perceptions of assurance.

$\mathbf{H}_{4}$ : There is a significant difference between customer expectations and their perceptions of empathy.

$\mathbf{H}_{5}$ : There is a significant difference between customer expectations and their perceptions of tangibility.

$\mathbf{H}_{6}$ : There is a significant difference between customer expectations and their perceptions of accessibility.

\subsection{Evaluation of Service Quality}

By calculating SERVQUAL scores, an assessment of private banks service quality was made. The findings are reported in tables as given below.

\subsection{SERVQUAL Dimensions}

The aim of this study is to find out whether a significant difference exists between Private Banks customers' service quality expectations and perceptions. Paired t-test was used to compare the means of expectations and perceptions for the 6 service quality dimensions.

In Table 3, a negative service quality gap indicates that respondents' expectations are greater than their perceptions. Positive service quality gap reflects perceptions of respondents exceed their expectations. Examining each of the 6 service quality dimensions, 6 negative service quality gaps were recorded. This depicted that the service quality rendered by the customers were lower than their expectations. Based on the results obtained in Table 3, all 6 hypotheses are accepted. So, one can conclude that there is a significant difference between customers' expectations and perceptions of the service quality of Private Banks. The bank is performing below the customers' expectations.

Table 2 also shows the mean perceptions and expectations of Private Banks customers for each dimension. In the reliability dimension, service gap is observed. The largest service gap in this dimension is in completing services at the right time. This means that there is some 


\section{MInstitute Macrothink $_{\text {Int }}$}

sort of delay occurs in performing customers' transactions. At the same time, Private Banks service is done at the maximum possible correct level as customers' perceptions exceed their expectations and a positive service gap is observed. When we consider the responsiveness dimension as a whole, it is clear that customers require that responsiveness in Private Banks services must be greater than its current level. Customers want to be informed when their services are done in a way better than the existing one. They also want employees to respond to their requests and enquiries. Finally, customers want Private Banks employees to serve them without any delay or hesitation. The service gap in this dimension has to be recognized by the top management and remedy actions are to be taken if Private Banks services are to be at the expectations level of customers.

From Table 2, it has been observed that the smallest service gap is in the assurance dimension where two statements exceeded expectations of customers. It is a proof that private banks employees are always polite when talking to customers and private banks customers feel confident that their transactions are complete and safe. Hence, to improve private banks customers' perceptions, management at all levels in private banks should focus on the functional aspects captured in the accessibility, responsiveness, and reliability dimensions rather than the technical aspects captured in the tangibility, assurance, and empathy dimensions.

Table 2: Mean scores of expectation (E), perception (P), and service quality for the 25 statements

Statements

(E) (P) SERVQUAL

(SQ)

Reliability

$\begin{array}{lll}3.94 & 3.85 & -0.09 *\end{array}$

Private banks performs my service as I want

$4.234 .10-0.13^{* *}$

Service is done right from the beginning

$3.913 .93+0.02^{*}$

I trust Private banks to solve any problem if occurred

$3.963 .80-0.16^{* *}$

Private banks completes the service at the right time

My records always come free of errors

Responsiveness

$\begin{array}{lll}3.84 & 3.67 & -0.17^{*}\end{array}$

I'm always informed when my service is done

$3.92 \quad 3.82-0.10^{* *}$

Private banks is always ready to respond to my requests

$3.77 \quad 3.68-0.09^{* *}$

Employees serve me without delay or hesitation

Assurance

$3.753 .62-0.13^{*}$

I trust Private banks employee who serves me

$\begin{array}{lll}3.8 & 3.73 & -0.07\end{array}$

$3.693 .60-0.09^{* *}$

I am confident that my transactions are complete and $3.89 \quad 3.92 \quad+0.03$ safe

Private banks employees are always polite when talking $\begin{array}{llll}3.85 & 3.88 & +0.03^{* *}\end{array}$ to me

Private banks employees have enough knowledge to $3.82 \quad 3.65 \quad-0.17^{* *}$ answer my questions 


\begin{tabular}{|c|c|c|c|}
\hline Empathy & 3.66 & 3.64 & $-0.02^{* *}$ \\
\hline $\begin{array}{l}\text { Private banks employees always give me special } \\
\text { attention }\end{array}$ & 3.80 & 3.80 & $0.00^{* *}$ \\
\hline $\begin{array}{l}\text { Private banks employees offer advice and guidance to } \\
\text { me }\end{array}$ & 3.43 & 3.42 & $-0.01^{* *}$ \\
\hline Private banks employees understand my needs & 3.71 & 3.64 & $-0.07^{* *}$ \\
\hline Tangibility & 3.93 & 3.91 & $-0.03^{* *}$ \\
\hline Private banks equipments are modern & 4.01 & 4.02 & $+0.01^{* *}$ \\
\hline Private banks layout is nicely done & 3.86 & 3.91 & $+0.05^{* *}$ \\
\hline Private banks is generally clean & 3.98 & 3.90 & $-0.08^{* *}$ \\
\hline Private banks accounting system is good & 4.03 & 3.87 & $-0.16^{* *}$ \\
\hline Private banks employees dress nicely & 3.75 & 3.79 & $+0.04^{* *}$ \\
\hline Accessibility & 3.70 & 3.58 & $-0.12^{* *}$ \\
\hline There are enough seats & 3.89 & 3.83 & $-0.06^{* *}$ \\
\hline Moving inside Private banks is easy & 3.78 & 3.77 & $-0.01^{* *}$ \\
\hline The location of Private banks is suitable & 3.84 & 3.77 & $-0.07^{* *}$ \\
\hline I can easily park my car & 3.40 & 3.12 & $-0.28^{* *}$ \\
\hline Private banks working hours are suitable & 3.73 & 3.68 & $-0.05^{* *}$ \\
\hline
\end{tabular}

is significant at $\mathrm{p}<0.05$

Table 6 shows the five highest expectations. These are private banks performs my service as I want (reliability dimension) with a corresponding service gap (-0.10), private banks equipments are modern (tangibility dimension) with no service gap is observed as customers found equipment as they expect, the level of cleanness in general (tangibility dimension) with a corresponding service gap (-0.09), the goodness of the accounting system (tangibility dimension) with a service gap (-0.11) and transactions are complete and safe (assurance dimension). The customers' responses show that private banks staff was neat and professional in appearance, promoted confidence in customers and their attitudes instilled in customers. Private Banks also were perceived to have up-to-date and well-maintained bank facilities and equipments, clean and comfortable environment with good directional signs. Table 4 reflects the five lowest expectations of customers. These are: I can easily park my car (accessibility dimension), employees offer advice and guidance to me (empathy), employees serve me without delays or hesitation (responsiveness), employees understand my needs (empathy), Private Banks working hours is suitable. It is clear that the customers' lowest expectations are in the empathy and accessibility dimensions.

According to the result of this study, the highest perceptions of private banks customers are showed in Table 6, these perceptions are consisting of some items such as: ' Private banks equipments are modern' (tangibility dimension), 'services are done rightly from the beginning' (reliability dimension), 'The bank performs my service as I want' (reliability dimension), 'I trust that my transactions are done completely and safely' (assurance dimension), and 'the layout is nicely done' (tangibility dimension). These perceptions show that Private banks is 


\section{Ml Macrothink}

Journal of Sociological Research

ISSN 1948-5468

2012, Vol. 3, No. 2

punctual in performing services with modern equipments, provide correct and free of errors services, has nice and neat layout, and finally customers are confident in the bank to perform their transactions in a safe and complete format. This means Private Banks customers are pleased to receive services from this bank.

The lowest perceptions of private bank customers are presented In Table 6 . These perceptions are consisting of (tangibility dimension), (empathy dimension), (accessibility dimension), (responsiveness dimension). This statement means that customers' perceptions are lower than their expectation for some services of private banks in Esfahan.

Table3. The five highest expectations

\begin{tabular}{|l|l|}
\hline Statement & $\begin{array}{l}\text { Statement } \\
\text { expectation }\end{array}$ \\
\hline Private banks performs my service as I want & 4.23 \\
\hline Private banks equipments are modern & 4.02 \\
\hline Private banks is generally clean & 3.90 \\
\hline Private banks accounting system is good & 3.87 \\
\hline $\begin{array}{l}\text { I trust Private banks to solve any problem if } \\
\text { occurred }\end{array}$ & 3.80 \\
\hline
\end{tabular}

Table4. The five lowest expectations

\begin{tabular}{|l|l|}
\hline Statement & Mean expectation \\
\hline I can easily park my car & 3.40 \\
\hline Private banks employees offer advice and guidance to me & 3.43 \\
\hline Employees serve me without delay or hesitation & 3.69 \\
\hline Private banks employees understand my needs & 3.71 \\
\hline Private banks working hours are suitable & 3.73 \\
\hline
\end{tabular}

Table5. The five highest perceptions

\begin{tabular}{|l|l|}
\hline Statement & $\begin{array}{l}\text { Mean } \\
\text { Perpetration }\end{array}$ \\
\hline Private banks performs my service as I want & 4.10 \\
\hline Private banks equipments are modern & 4.07 \\
\hline Service is done right from the beginning & 3.98 \\
\hline $\begin{array}{l}\text { I am confident that my transactions are complete and } \\
\text { safe }\end{array}$ & 3.97 \\
\hline
\end{tabular}


Table6. The five lowest perceptions

\begin{tabular}{|l|l|}
\hline Statement & Mean expectation \\
\hline I can easily park my car & 3.17 \\
\hline Private banks employees offer advice and guidance to me & 3.47 \\
\hline Private banks working hours are suitable & 3.63 \\
\hline Employees serve me without delay or hesitation & 3.65 \\
\hline I'm always informed when my service is done & 3.67 \\
\hline
\end{tabular}

Table 7 presented the largest service gap relating to this study. The mentioned gap are consisting of (1) I can park my car easily (related to accessibility), other largest gap of Private Banks services are related to (2) (assurance), (3) (accessibility), (4) (reliability).

Table7. The five largest service gaps (SQ)

\begin{tabular}{|l|l|}
\hline Statement & $\begin{array}{l}\text { Mean } \\
\text { expectation }\end{array}$ \\
\hline I can easily park my car & -0.27 \\
\hline $\begin{array}{l}\text { Private banks employees have enough knowledge to answer my } \\
\text { questions }\end{array}$ & -0.16 \\
\hline Private banks working hours are suitable & -0.14 \\
\hline Private banks completes the service at the right time & -0.14 \\
\hline I trust Private banks to solve any problem if occurred & -0.14 \\
\hline
\end{tabular}

In table 8 , all of 5 the five SERVQUAL dimensions which have minimum service gaps are showed. The mentioned dimension are consisting of (empathy dimension), (accessibility dimension), (responsiveness dimension), (accessibility dimension), and (accessibility dimension). Accessibility and empathy dimensions have the minimum services gap for the private banks.

Table8. The five smallest service gaps (SQ)

\begin{tabular}{|l|l|}
\hline Statement & Mean expectation \\
\hline Private banks employees offer advice and guidance to me & -0.01 \\
\hline Moving inside Private banks is easy & -0.03 \\
\hline Private banks is always ready to respond to my requests & -0.05 \\
\hline There are enough seats & -0.05 \\
\hline The location of Private banks is suitable & -0.06 \\
\hline
\end{tabular}




\subsection{The Result of Analysis of the Relative Importance}

In SERVQUAL, both service performance and consumer expectations of the service quality are explicitly measured to assess the gap. Several researchers find the performance perceptions to be sufficient in assessing service quality as compared to the gap (Parasuraman et al, 1988). In fact, one of the valuable elements of the SERVQUAL analysis is the ability to determine the relative importance of the dimensions as determined by the customers. In Table 9 the relative importance of every of the SERVQUAL dimensions was showed. According to the result, Assurance dimension has the more relative important (40.6\%).

Table9. Analysis of the relative importance of SERVQUAL dimensions

\begin{tabular}{|l|l|}
\hline Dimension & Relative importance (\%) \\
\hline Reliability & $27.3 \%$ \\
\hline Responsiveness & $15.9 \%$ \\
\hline Assurance & $34.9 \%$ \\
\hline Empathy & $8.3 \%$ \\
\hline Tangibility & $6.1 \%$ \\
\hline Accessibility & $7.2 \%$ \\
\hline
\end{tabular}

Table 10 shows all results relating to computing of the unweighted score accordance to the dimensions of SERVQUAL. According to the result of current study, the most negative unweighted SERVQUAL is devoted to the Accessibility. In addition, The Assurance, as a most effective dimension of SERVQUAL, has the minimum negative unweighted SERVQUAL comparing to other dimensions. Reliability, which is the second effective dimension, has the second most negative unweighted SERVQUAL. Other dimensions of this research consisting of Responsiveness, Empathy, Tangibility have negative un weighted SERVQUAL.

\section{Table10. The unweighted SQ}

\begin{tabular}{|l|l|}
\hline Dimension & Mean unweighted score \\
\hline Reliability & -0.080 \\
\hline Responsiveness & -0.080 \\
\hline Assurance & -0.020 \\
\hline Empathy & -0.026 \\
\hline Tangibility & -0.030 \\
\hline Accessibility & -0.110 \\
\hline SQ (unweighted) & -0.058 \\
\hline
\end{tabular}


Table11. The weighted SQ

\begin{tabular}{|l|l|}
\hline Dimension & Mean weighted score \\
\hline Reliability & -0.062 \\
\hline Responsiveness & -0.044 \\
\hline Assurance & +0.006 \\
\hline Empathy & +0.003 \\
\hline Tangibility & -0.055 \\
\hline Accessibility & -0.079 \\
\hline SQ (unweighted) & -0.039 \\
\hline
\end{tabular}

\subsection{Analysis Of Overall Quality Rating}

The quality rating of Private Banks services is shown in Table 12 as seen by customers. In this table, $28.7 \%$ of customers rated the services as very good with SQ $+0.16,39.1 \%$ rated the services as good with SQ $-0.03,24.7 \%$ rated them as fair with SQ -0.26 , 5\% rated Private Banks services as poor with SQ -0.39 and only $1.5 \%$ of Private banks customers rated services as very poor with a corresponding SQ -0.17 . For customers who rated Private Banks services as good and very good (67.8\%), SQ is better than the average SQ which is -0.058 . However, the rest $(31.2 \%)$ considered service quality below their expectations. The least favorable score $(-0.52)$ is in the reliability dimension for those who rated the overall quality of Private Banks services poor. The most favorable score (0.27) is in the assurance dimension for those who rated the overall quality of Private Banks services very good.

Table12. Analysis of the overall quality rating

\begin{tabular}{|l|l|l|l|l|l|l|l|}
\hline Rating & Reliability & Responsiveness & Assurance & Empathy & Tangibility & Accessibility & SQ \\
\hline $\begin{array}{l}\text { Very } \\
\text { poor }\end{array}$ & 0.13 & 0.00 & -0.33 & -0.33 & -0.22 & -0.26 & -0.17 \\
\hline Poor & -0.52 & -0.46 & -0.28 & -0.28 & -0.26 & -0.24 & -0.39 \\
\hline Fair & -0.08 & -0.27 & -0.30 & -0.21 & -0.36 & -0.34 & -0.26 \\
\hline Good & -0.11 & 0.00 & 0.00 & 0.02 & 0.04 & -0.13 & -0.03 \\
\hline $\begin{array}{l}\text { Very } \\
\text { good }\end{array}$ & 0.07 & 0.03 & 0.27 & 0.20 & 0.16 & 0.16 & 0.16 \\
\hline
\end{tabular}


In this section, some of the remarkable results of this study summarized as following:

-some service gap was observed in the quality of services which provided by Private Banks in Esfahan area. The most important gap regarding to service quality in this study is in the accessibility dimension. Furthermore, the Private Banks should manage and decrease the service gap.

- Private Banks employees dress nicely and they are polite when talking to customers.

- $67.8 \%$ of Private Banks customers rated the overall service quality as good and very good. This result should be seriously taken by Private Banks management to improve their services and retain their customers.

- On average, Private Banks customers rated the overall service quality as good (3.9 out of 5).

- Customers' expectations of Private Banks services are highest in reliability dimension.

- Private Banks has exceeded customers' expectations in performing the service right from the beginning and in instilling the confidence in customers that their transactions are complete and safe.

\section{Conclusion}

In this paper, we have shown that it is important in the analysis of service quality to use the SERVQUAL as a technique necessary to explore the most important strength and weaknesses in a service provider. The application in this paper was on Private Banks in Esfahan. Many gaps in Private Banks services have been discovered. Despite the fact that none of these gaps is serious, Private Banks has to devote their efforts to cover these gaps especially the accessibility gap.

Private Banks customers considered the level of services below their expectations. This means that Private Banks has to do the maximum efforts that it can afford to raise the level of services in these dimensions to the level of customers' expectations. In the accessibility dimension, car parking seems to be the most serious problem. Therefore, Private Banks management has to solve this problem as soon as possible. In reliability dimension, the most serious service gap is in performing customers' transactions at the right time. Private Banks should search for the reasons of delays. Moreover, performing services as customers want is another service gap in this dimension and it should also be tackled. As assurance dimension seems to be the most important dimension to Private Banks customers, the widest gap was found in the sufficiency of employees' knowledge to answer customers' questions. In this respect, Private Banks management has to increase the knowledge of the employees by providing training courses in their deficiency areas. 


\section{References}

Almoosavi, M., (2001), Bank Selection Criteria Employed by College Student in Bahrain: An Empirical Analysis. International Journal of Bank Marketing. 19(3), pp115-125.

Bergman, B. and Klefsjo, B. (1994) Quality: From Customer Needs to Customer Satisfaction, New York, NY:McGraw-Hill.

Boyd, W. L., Leonard, M., \& White, C. (1994) Consumer Preferences for financial services: An analysis. International Journal of Bank Marketing, 12(2), pp9-15.

Brannen, S.J. and Streeter, C.L. (1995). "Doing It with Data: Total Quality Management and the Evaluation of Social Services." In: B. Gummer and P. McCallion (Eds.), Total Quality Management in the Social Services: Theory and Practice, Albany, NY: Rockefeller College Press, pp 59-88.

Chen, T. Y. 1999 Critical success factors for various strategies in the banking industry. International Journal of Bank Marketing, IV ( $\$ ), ^ \ -( 9 Christopher, L and Lauren, W, (1991), Principal of Service Marketing and Management, Prentice Hall, USA.

Cobb-Walgren, C. J., Ruble, C. A., \& Donthu, N. (1995), Brand equity, brand preference, and purchase intent. Journal of Advertising, 24(3), pp25-40.

Edris, T. A., \& Almahmeed, M. A. (1997) Servieces considered important to business customer and determinants of bank selection in Kuwait: A segmentation analysis. International Journal of Bank Marketing, 15(4), pp126-133.

Evans, J.R. and Lindasy, W. M. (1996) .the Management and Control of Quality. New York, NY: West publishing Company.

Gronroos, C.(1984). “A Service Quality Model and Its Implications.” European Journal of Marketing,

8,pp 36-44.

Jannadi, O.A. and Al-Saqqaf, H. (2000) "Measurement of Quality in Saudi Arabian Service Industry.”International Journal of Quality and Reliability Management, 17(9), pp 949-965.

Lewis, R.C. and Booms, B. H. “The Marketing Aspects of Quality.” In: L. Berry, L. Shostack and 


\section{Macrothink}

Journal of Sociological Research

ISSN 1948-5468

2012, Vol. 3, No. 2

G.Upah (Eds.),(1983). Emerging Perspectives on Service Marketing. Chicago, IL: American Marketing Association .pp, 99-107.

Parasuraman, A., Zeithaml, A. and Berry, L.L.(1985). "A Conceptual Model of Service Quality and Its Implications for Future Research.” Journal of Marketing, 49.pp 41-50.

Parasuraman, A., Zeithaml, V. A. and Berry, L. L.(1988) "SERVQUAL: A Multiple-item Scale for Measuring Consumer Perceptions of Service Quality.” Journal of Retailing, 64,pp $12-40$.

Prasuraman, A., Zeithaml, V. A. and Berry, L. L.(1991). "Refinement and Reassessment of the SERVQUAL Scale.” Journal of Retailing, 67(4), pp 419-450.

Reichheld, F.F. and Sasser, W. E. Jr. (1990) "Zero Defections: Quality Comes to Services." Harvard Business Review, September - October, pp 105-111.

Selber, K.(1998) "Challenges in Measuring and Managing Quality in Health and Human Services Organizations.” Family and Community Health, 21(2), pp 50-69.

Ta, H. P., \& Har, K. Y. (2000) A study of bank selection decisions in singapore using the analytical hierarchy process. International Journal of Bank Marketing, 18(4), pp170-180.

Walsh, K.(1991) “Quality and Public Services.” Public Administration, 69(4),pp 503-514. 